\title{
THE EFFECT OF USING CONTEXTUAL TEACHING AND LEARNING (CTL) METHOD ON STUDENTS' ACHIEVEMENT IN WRITING RECOUNT TEXT
}

\author{
*Putri Masrita Lubis \\ **Willem Saragih
}

\begin{abstract}
This study aims at investigating the effect of using Contextual Teaching and Learning (CTL) Method on Students' Achievement in Writing Recount Text. This study was conducted by experimental research. The population of this study was the students of the tenth grade of SMA SWASTA SULTAN ISKANDAR MUDA MEDAN. The total number of the population was one hundred sixty students in 6 classes. There were sixty students chosen as the sample by using random sampling technique. The sample was divided into two groups, namely control group and experimental group. The experimental group was taught by using CTL Method and control group was taught without using CTL Method. The instrument for collecting the data was writing test. The data was analyzed by using t-test formula. The result of the analysis shows that t-observed value is higher than t-table $(2.34>2.00)$ at level of significance 0.05 with the degree of freedom 58. It means that the alternative hypothesis (Ha) is accepted and null hypothesis (Ho) is rejected. Based on the findings of this study, it was found that there is a significant effect of Contextual Teaching and Learning (CTL) Method on students' achievement in writing recount text.
\end{abstract}

Key words: Writing, gendre, recount text, Contextual Teaching and Learning (CTL)

\footnotetext{
* A graduate of English Language and Literature Department of UNIMED

** A lecturer of English Language and Literature Department of UNIMED
} 


\section{INTRODUCTION}

\section{Background of the Study}

Writing is one of the most important skills in learning a language besides listening, speaking, andreading. It is an expression form of someone that pours it in form of letter. Because of that, writing process need much time to think about what ideas that people will develops in their writing.

Writing is the last language skill and it is considered by many people as a difficult skill to be studied. In writing, there is a process of arranging letters, words, sentences and paragraph to another. It is also an essential skill, which expresses a speech to a group of visual symbols.

Writing is one of four language skills which has important role in conveying thoughts, ideas or opinions in written form. Writing serves as the most available and the most compelling way because the outcome, visible language, is a satisfying permanent record of thoughts and feelings. Writing is the mental work of the inventions ideas, thinking about how to express them into statement and paragraph that will be clear to a reader.

Genre is an approach to teaching writing which focuses on creating authentic writing in school. Hyland (2002:17) defines a genre as a staged, goal-oriented social process. He explains that teaching genres involves increasing learners' awareness of the conventions of writing to help them produce texts that seem well-formed and appropriate to readers. In Educational Unit Curriculum (KTSP:2007), there are seven kinds of genre are taught in senior high school, namely:

* Descriptive text is a text which says what a person or a thing is like. Its purpose is to describe and reveal a particular person, place, or thing.

* Narrative text is to amuse/entertain the readers and to tell a story. It always appears as a hard portrait of participant's past experience and it has conflict among the participants.

- Recount text is a text which retells events or experiences in the past. Its purpose is either or to entertain the readers. It has not conflict among the participant.

* Procedure text is a text show a process in order. Its function is to describe how something is completely done through a sequence of series.

* Report text is a text which presents information about something, as it is. It is as a result of systematic observation and analysis.

* Explanation text is a text which tells processes relating to forming of natural, social, scientific and cultural phenomena.

* Spoof text is a text which tells factual story, happened in the past time with unpredictable and funny ending. Its purpose is to entertain and share the story, and so forth.

Recount is a text which retells events or experiences in the past. The purpose of recount is to list and describe past experience by retelling events in which they happened (chronological order). The events in the recount are the main element in 
composing the text. However it just focuses on the events themselves. It does not include the conflict inside.

There are three types of a recount, those are:

a) Personal Recount

It means that retelling an activity that the writer/speaker has been personally involved. The followings are the language feature of personal recount:

- Use of the first person pronouns, such as, I and we

- Personal responses to the events can be include, particularly at the end.

- Details are often chose to add interest or rumor

\section{b) Factual Recount}

It means that recording the particulars of an incident. The following are the language feature of factual recount:

- Use of third person pronouns, such as : he, she, it and they

- Details are usually selected to help the reader reconstruct the activity or incidents accurately

- Sometimes, the ending describes the outcome of the activity (eq. In a science experiment)

- Mention of personal feelings is probably not appropriate

- Details of time, place and manner may read or be precisely stated

- Desrcriptive details may also be required to provide precise information

- The passive voice may be used

- It may be appropriate to include explanations and justifications

\section{c) Imaginative Recount}

It means that taking an imaginary role and giving details of events. The following are the language feature of imaginative recount:

- It usually written in the first person

- It may be appropriate to include personal reaction 


\section{Research Question}

The problem of the study was formulated as the following: Does the effect of Contextual Teaching and Learning (CTL) method improve writing achievement of the students of the tenth grade at Swasta Sultan Iskandar Muda Medan?

\section{Conceptual Framework}

\section{Generic Structure of Recount text}

Generic structure of recount text are:

\section{1) Orientation}

The text structure of a recount starts with an orientation. It tells to readers the aim idea of the story being discussed in the text. Orientation gives a setting of the story, so that readers are aware of the story is about. Orientation tells the reader who was involved, what happened, where this events took place and when it happened.

2) Events

In this part, the story stars from the very early stages. The story develops based on the sequence of the events. Events describe series of event that happened in the past.

\section{3) Re-orientation}

This part is optional, stating personal comment of the writer to the story. The writer will wrap story up in re-orientation. The witer summarizes the story and tells his/ her impression of the experience that what has been elaborated.

In the following recount, the writer has simply taken a simple story, taken from Knap and Watkins (2005:225). The example of recount text is :

Once there was an old man. His wife had died and he had married again. The man had one son and his step mother had a daughter.

\section{Orientation}


One day the man and his son went to collecting fire wood.

Event

They saw a golden tree. They went slowly over to the tree. When they got closer to the tree heard a voice coming from the tree. This are what the tree said, "Go north for one miles, then you will find a fairy wearing a gold ring. You must take the ring and make wish."

They found the fairy and lived happy ever after.

Re-orientation

The example of recount paragraph :

\section{My Adventure at Leang Cave}

Orientation : On Sunday, my parents, my best friend Novi, and I visited a cave at Maros called Leang-leang. It was my first time to visit the cave, better yet, my best friend came to visit it with me.

Event 1: The cave was famous for its primitive cave wall paintings which were some hand prints and wild boar paintings. The cave and its surroundings was turned into a national park, so it was taken care of. My parents took a rest in a small hut for visitors the park, while Novi and I adventured around the cave with a guide. We had to climb some metal stairs to get to the cave, because the cave was embedded into a small mountain. Next stop was a place where some seashells littered the ground and some were actually piled into a big mound. The guide said that these piles of seashells are called 'kjokkenmoddinger', or 'kitchen trash'.

Event 2: The humans who lived here ate the shells and dumped the left overs in their 'kitchen'. The last place was a small museum where they have skeletons of the humans who lived in the caves. The skeletons along with some roughly made jewelry and weapons were placed inside glass cases for display. The walls of the museum were adorned with photographs taken when they did an exacavation there.

Reorientation : After a quick lunch with Novi and my parents, we decided it was time to go back home. We really had the time of our lives.

\section{Contextual Teaching and Learning}

Contextual Teaching and Learning is one of the methods which can be applied to improve students' achievement in learning process. It can help students to increase students' achievement in writing recount paragraph by connecting the context with students daily live.

This method not only helps students in improving teaching and learning process but also help teacher in teaching process. CTL call as contextual approach because the concept helps teacher to connect the material of teaching with students daily lives so 
that motivates students to connect the relationship between knowledge that they have with the implementation in their daily lives.

Johnson (2002:25) says that the contextual teaching and learning system is an educational process that aims to help students see meaning in the academic material they are studying by connecting academic subjects with the context of their daily lives, that is, with the context of their personal, social, and cultural circumstance. To achieve this aim, the system encompasses the following eight components; 1). Making meaningful connections, 2). Doing significant work, 3). Self-regulated learning, 4).Collaborating, 5).Critical thinking, 6). Nurturing the individual, 7). Reaching high standards, and 8). Using authentic assessment.

\section{The Component of CTL}

\section{1) Constructivism}

According to Spivey (1997) in Brown (2000), the constructivism is an emphasis on active process of construction (of meaning) attention to texts as a means of gaining insight into those processes and interest in the nature of knowledge and its variations, including the nature of knowledge associated with the membership in particular group.

The task of the teacher is to facilitate the constructivism process as follow:

1. Making meaningful knowledge and relevant for students

2. Giving opportunity for students to propose and to apply their ideas

3. Making students aware for applying their own strategy in study.

\section{2) Inquiry}

Inquiry is core part of CTL. It is designed to meet the needs of students at their own development level with their understanding of concept. Students will be independent learners with their curiously to know and explore something with guidance of the teacher. The key word of inquiry is students seek out the information and skill by themselves, Department of National Education(2003: 12).

When the students want to get information, they will ask some questions based on the observation result and then hypothesis will be done in the process of decision making. There are some activities needed in the applying of inquiry. The activities are formulating problem, doing observation, analyzing and presenting result in the form of writing, report, table list and other work.

\section{3) Questioning}

Questioning is viewed as the teacher activity to support, guide and evaluate the students' thinking skill. While it is used by the students in doing activities based on inquiry, Department of National Education (2003:14).

Questioning usually appears if students find difficulties in learning process, when students find problem, questioning will form automatically. Questioning is not merely happening between students and teacher but it could be happened among students too.

\section{4) Learning Community}

According to Department of National Education (2003:15), learning community is taking and gives activity to help learning process in the class. 
Learning community is established in workplace and schools in an effort to share knowledge focus on goals and allow all to teach and learn from each other. In other words, learning is not only done in class but it can come from society. Learning community can be started from small group or called as group work. In this small group, among students could give input one to others.

\section{5) Modeling}

According to Department of National Education (2003:16), modeling is to give something in doing something, in teaching learning process, modeling in CTL dedicated to support learning process; the model can be imitated or observed by the students. A model can operate and demonstrate something. The model is not only from the teacher but also can be constructed by involving the students who have ability for the study. Teacher asks for another student to describe their experience orally by using questioning approach.

\section{6) Reflection}

Reflection is the way of thinking what they have just learnt or what they have done in the past. In this case, the students review and respond events, activities or knowledge that they have just accepted. In learning process, reflection can be found in the form of presentation, note, suggestion or discussion. In telling experience, implementation or reflection will be presented to the teacher and classmates, and later on, the audiences are going to give comments to the presentation. Comments of presentation have been done by themselves. Thus, the teacher takes part to give input, so the students are motivated to give the best of their presentation.

\section{7) Authentic Assessment}

The point uses to assess students' achievement are: students' performance or presentation, homework, demonstration, quiz, journal, report, students' activity and written test, Department of National Education (2003:19).

Authentic assessment is used to describe the form of assessment which can describe students' result of learning motivation, learning acquisition, and attitudes toward relevant learning to classroom activities. O' Malley, (1996:4).

CTL plays important role for teacher to motivate and develops students' interest in teaching and learning process. All of the components of CTL can be conducted in applying CTL in the classroom, such as: developed thought that students will learn more meaningful by finding and constructing their by themselves; inquiry for all topics; develops students' curiosity by asking; create learning community and present a model in teaching and learning; do a reflection in the end of meeting; moreover, do authentic assessment in various ways.

\section{METHODOLOGY}

\section{Population}

Sukardi (2003) stated that a population is all members of well defined class of people or objects. In this study the researcher chose the tenth grade students of SMA Swasta Sultan Iskandar Muda Medan as the population of this research. There were 6 parallel classes. The total numbers of students were 160 students. 


\section{Sample}

Ary (1979) stated that a sample is a small group which is observed. In selecting the sample, the researcher used Random Sampling Technique as the sampling technique. The sample was taken 2 classes. The experimental group was class X-a and the control group was class X-d. The experimental Group was taught writing recount text by using Contextual Teaching and Learning method while the control group was taught by using conventional method.

\section{Instrument for Collecting Data}

This research was used writing essay test as an instrument to collect the data. In this case, the same test in pre-test and post-test were given to the experimental and control groups. The students were asked to write an essay. The topic was adjusted based on the curriculum that was implied in the senior high school text book.

\section{The Procedures of the Study}

In order to get the data in this study, three procedures were taken by the writer namely: pre-test, treatment (teaching presentation), and post-test.

Pre-Test

The pre-test was gave out to both groups (experimental group and control group) before the treatment. The pre-test was used to know the mean scores of the experimental group and control group before receiving treatment. The students were asked to write an essay.

\section{Treatment}

After the pre-test was carried out to both experimental and control group. The experimental group was taught by using CTL method in writing. In control group, the students were applied conventional method on students writing.

Post - Test

Post-test was given to both of the experimental and control group after conducting the treatment in order to get the mean score between experimental and control group. Moreover, it purposes to know whether CTL method has a significant effect on the students' achievement in writing recount text or not.

\section{Conclusion and Suggestion}

\section{Conclusion}

The result of calculation of t-test shows that $t_{\text {-test }}$ value 2.34 with the degree of freedom $(\mathrm{df})=58$ is higher than $\mathrm{t}$ table 2.00 at the level significance $(\mathrm{p}=0.05)$ which implies that the alternative hypothesis (Ha) is accepted and null hypothesis (Ho) is rejected. Therefore, there is a significant effect of Contextual Teaching and Learning Method on the achievement of the tenth grade students of SMA SWASTA SULTAN ISKANDAR MUDA in writing recount text.

\section{Suggestions}


Based on the conclusion drawn above, it is suggested that:

a. English teachers apply Contextual Teaching and Learning method as the alternative and interesting method in teaching of writing recount text or other genres, because it can improve the students' achievement in writing text.

b. English learners enlarge their knowledge to write in English and to improve their writing achievement by using CTL method.

c. Other researchers who are interested in conducting study in writing recount text by using CTL method use this finding as their references.

\section{References}

Aruan, D.M. 2007. Penafsiran Skor Test. Medan: Universitas Negeri (Unpublished).

Brown, H. D. 2001. Teaching by Principles: An interactive Approach to Language Pedagogy. $2^{\text {nd }}$ edition. San Fransisco: Longman.

Brown, H. D. 2004. Language Assessment Principles and Classroom Practices. San Francisco State University: Longman.

Department of National Education. 2003. Pendekatam Kontekstual (Contextual Teaching and Learning-CTL). Jakarta. Depdiknas.

Gerot, Linda and Peter Wignell. 1994. Making Sense of Functional Grammar. Gerd Stabler. Sidney.

Harmer, Jeremy. 2003. How to Teach Writing. New York: Longman.

Harmer, Jeremy. 2003. The Practice of English Language Teaching. $3^{\text {rd }}$ ed. Cambridge: Longman.

Hornby, AS. 1989. Oxford Advance Learners Dictionary of Current English. Oxford: Oxford University Press.

Houghton Miffin. 1989. American Heritage Dictionary.USA: USA University Press.

Hutapea, Putri. 2010. Improving Students' Skill Achievement in Speaking Through Contextual Teaching and Learning Strategy. Medan: UNIMED.

Hyland, K. 2002. Teaching and Researching Writing. London: Pearson Education Limited.

Johnson, E. B. 2002. Contextual Teaching and Learning: Corwin Press; Inc. Thousand Darks. California.

Johnson, E. B. 2002. Contextual Teaching and Learning: What is it and why it here to stay. California: Corwin. 
Knapp, P. And M. Watkins. 2005. Genre, Text, Grammar: Technologies for Teaching and Assessing Writing. Sydney: University of New South Wales Press.

Kurikulum Tingkat Satuan Pendidikan (KTSP). 2006. Tentang STANDAR ISI Untuk Satuan Pendidikan Dasar dan Menengah. PERMEN Nomor 22 Tahun 2006.

Langan, John. 2001. College Writing Skills with Reading. New York: Mc Graw Hill

Nunan, D. 2003. Practical English Language Teaching. New York: Mc. Graw Hill

O’ Malley, A. M. and Pierre. L. V. 1996. Authentic Assessment for English Learners. USA: Addison - Wesley Publishing Company

Sitepu, Andriyani. 2010. The Effect of Using Contextual Teaching and Learning in Teaching Conditional Sentences. Medan: UNIMED Press

Stott, Rebecca and Simon Avery. 2001. Writing with Style. England: Longman

Taufiq, Muhammad. 2010. Improving Students' skill in writing Recount through Contextual Teaching and Learning. Medan: UNIMED Press

Tiwari, Deepak. 2005. Encyclopedia of Modern Methods of Teaching. Volume 7. New Delhi: Crescent Publishing Corporation.

http://www.cew.wisc.edu/teachnet/ctl/by Jennice M. downloaded September 16th, 2011

http://fandi4tarakan.wordpress.com/2009/12/26/pengertian-ctl-pembelajarancontextual-teaching-and-learning/ by Fandi. Downloaded September 16th, 2011 


\section{APPENDIXES}

APPENDIX A

Students score of Pre-Test and Post-Test of Experimental Group

\begin{tabular}{|c|c|c|c|}
\hline No. & $\begin{array}{c}\text { Students' Initial } \\
\text { Name }\end{array}$ & $\begin{array}{c}\text { Pre-Test } \\
\text { (T1) }\end{array}$ & $\begin{array}{c}\text { Post-Test } \\
\text { (T2) }\end{array}$ \\
\hline 1. & $\overline{\mathrm{AI}}$ & 49 & 54 \\
\hline 2. & CAD & 60 & 88 \\
\hline 3. & $\mathrm{CN}$ & 76 & 80 \\
\hline 4. & DA & 55 & 85 \\
\hline 5. & DB & 80 & 91 \\
\hline 6. & $\overline{\mathrm{DN}}$ & 65 & 95 \\
\hline 7. & FP & 82 & 89 \\
\hline 8. & FW & 67 & 77 \\
\hline 9. & IA & 47 & 70 \\
\hline 10. & IS & 74 & 82 \\
\hline 11. & JS & 66 & 92 \\
\hline 12. & KA & 70 & 74 \\
\hline 13. & $\mathrm{KH}$ & 56 & 70 \\
\hline 14. & $\mathrm{LS}$ & 78 & 95 \\
\hline 15. & NAS & 55 & 68 \\
\hline
\end{tabular}




\begin{tabular}{|c|c|c|c|}
\hline 16. & $\mathrm{ND}$ & 76 & 80 \\
\hline 17. & NIY & 74 & 80 \\
\hline 18. & NR & 65 & 85 \\
\hline 19. & $\mathrm{RD}$ & 75 & 95 \\
\hline 20. & $\mathrm{RF}$ & 70 & 93 \\
\hline 21. & RFS & 73 & 75 \\
\hline 22. & $\overline{\mathrm{RM}}$ & 80 & 95 \\
\hline 23. & RW & 70 & 73 \\
\hline 24. & SA & 82 & 85 \\
\hline 25. & SH & 60 & 70 \\
\hline 26. & SY & 64 & 45 \\
\hline 27. & $\mathrm{VG}$ & 70 & 78 \\
\hline 28. & WW & 60 & 69 \\
\hline 29. & YG & 42 & 84 \\
\hline 30. & $\overline{\mathrm{YT}}$ & 72 & 80 \\
\hline & Total $\left(\sum\right)$ & 2013 & 2418 \\
\hline & Mean (X) & 67.1 & 80.6 \\
\hline
\end{tabular}

APPENDIX B

Students score of Pre-Test and Post-Test of Control Group

\begin{tabular}{|c|l|c|c|}
\hline No. & $\begin{array}{c}\text { Students' Initial } \\
\text { Name }\end{array}$ & $\begin{array}{c}\text { Pre-Test } \\
\text { (T1) }\end{array}$ & $\begin{array}{c}\text { Post-Test } \\
\text { (T2) }\end{array}$ \\
\hline 1. & AAN & 52 & 54 \\
\hline 2. & AS & 41 & 38 \\
\hline 3. & AT & 27 & 50 \\
\hline 4. & BD & 32 & 50 \\
\hline
\end{tabular}




\begin{tabular}{|c|c|c|c|}
\hline 5. & BL & 52 & 55 \\
\hline 6. & DA & 57 & 60 \\
\hline 7. & DFA & 50 & 70 \\
\hline 8. & $\overline{\mathrm{DK}}$ & 48 & 50 \\
\hline 9. & DKN & 45 & 55 \\
\hline 10. & DS & 35 & 45 \\
\hline 11. & EIP & 40 & 55 \\
\hline 12. & $\overline{E L}$ & 60 & 50 \\
\hline 13. & EM & 48 & 54 \\
\hline 14. & EW & 37 & 70 \\
\hline 15. & FR & 62 & 65 \\
\hline 16. & $\begin{array}{l}\text { FT (1) }\end{array}$ & 40 & 50 \\
\hline 17. & FT (2) & 45 & 54 \\
\hline 18. & HM & 60 & 65 \\
\hline 19. & IA & 58 & 60 \\
\hline 20 . & IS & 56 & 62 \\
\hline 21. & ISY & 56 & 75 \\
\hline 22 . & $\begin{array}{l}\text { IT } \\
\end{array}$ & 48 & 55 \\
\hline 23. & LH & 47 & 40 \\
\hline 24. & $\mathrm{MC}$ & 60 & 65 \\
\hline 25. & $\mathrm{MN}$ & 40 & 55 \\
\hline 26. & MRP & 40 & 50 \\
\hline 27. & MS & 60 & 70 \\
\hline 28. & $\mathrm{NC}$ & 67 & 62 \\
\hline 29. & OK & 50 & 55 \\
\hline 30. & RH & 42 & 50 \\
\hline
\end{tabular}




\begin{tabular}{|l|l|c|c|}
\hline & Total $(\Sigma)$ & 1455 & 1680 \\
\hline & Mean $(X)$ & 48.5 & 56 \\
\hline
\end{tabular}

